\title{
ANALISIS EKONOMI-EKOLOGI UNTUK PERENCANAAN PEMBANGUNAN PERIKANAN BUDIDAYA BERKELANJUTAN DI WILAYAH PESISIR PROVINSI BANTEN
}

\author{
Yoga Candra Ditya ${ }^{1}$, Luky Adrianto², Rokhmin Dahuri² dan Setyo Budi Susilo \\ ${ }^{1}$ Peneliti pada Balai Penelitian Perikanan Perairan Umum \\ ${ }^{2}$ Dosen pada Fakultas Perikanan dan IImu Kelautan-Institut Pertanian Bogor \\ Email: yogakoko@yahoo.co.uk
}

Diterima 10 April 2012 - Disetujui 3 Desember 2012

\begin{abstract}
ABSTRAK
Dalam perencanaan wilayah pesisir Provinsi Banten, perikanan budidaya memiliki peran penting terhadap nilai sosial dan ekonomi, terutama dalam hubungannya dengan aktivitas ekspor dari produk perikanan budidaya tersebut. Namun demikian, aktivitas perikanan budidaya juga berpotensi memberikan multiplier negatif jika dipandang dari segi efek yang ditimbulkan ke lingkungan pesisir, terutama ketika tidak ada pengelolaan yang baik pada aktivitas tersebut. Tujuan penelitian ini adalah (1) Menelaah kekuatan struktur dan interaksi antar sektor dari perikanan budidaya; (2) Mengestimasi dampak ekonomi dan ekologi dari pembangunan perikanan budidaya; dan (3) Mengestimasi daya dukung lingkungan pesisir yang dapat dimanfaatkan bagi kegiatan perikanan budidaya berkelanjutan. Untuk menjawab tujuan tersebut, dibangun model ecological input-output dan pendekatan ecological footprint. Hasil penelitian menunjukkan bahwa indeks keterkaitan ke belakang $(1,84)$ lebih tinggi daripada keterkaitan ke depan $(1,02)$. Hal ini berarti bahwa aktivitas perikanan budidaya di Provinsi Banten lebih memiliki kemampuan dalam menarik sektor hulu dibandingkan dengan sektor hilirnya. Lebih lanjut, pembangunan perikanan budidaya juga memberikan multiplier ekonomi yang memiliki income multiplier $(2,20)$ lebih tinggi dibandingkan employment multipliernya $(1,17)$. Dari segi ecological multiplier, area mangrove memberikan indeks sebesar 0,005, COD (0,001), dan TDS (0,001). Penggunaan pendekatan ecological footprint, diestimasikan bahwa daya dukung dari area pesisir yang tersedia adalah pada level 48.886 ha dengan target permintaan 497.825,59 juta rupiah.
\end{abstract}

Kata Kunci: pembangunan perikanan budidaya, ecological input-output, ecological footprint, wilayah pesisir Banten

\section{Abstract: Ecological-Economic Analysis of Sustainable Aquaculture Development Planning in the Coastal Zone of Banten Province. By: Yoga Candra Ditya, Luky Adrianto, Rokhmin Dahuri and Setyo Budi Susilo.}

In the planning of Banten coastal zone, aquaculture has important role due to its social and economic value especially related with export activities of the aquaculture products. However, aquaculture activities potentially have also a negative multiplier effect on the coastal environment, especially when there is no proper management of those activities. The aims of this research are (1) to identify the structure and interaction among sectors in aquaculture activities; (2) to estimate the economic and ecological impact of the aquaculture activities, and ;(3) to estimate carrying capacity of the coastal area enabling for sustaining aquaculture development. To achieve these objectives, ecological input-output model was developed and supported with ecological footprint approach. Results of the study reveal that backward linkages index (1.84) is higher than forward linkages one (1.02). This means that aquaculture activities in Banten Province has capacity to pull upstream sectors rather than downstream sectors. Furthermore, aquaculture developmant has also produced economic multiplier by which income multiplier is (2.20) higher than 
employment multiplier (1.17). From the ecological multiplier point of view, mangrove area producs index as of 0.005, COD (0.001), and TDS (0.001). Using ecological footprint approach, the carrying capacity of appropriated coastal area is estimated at the level of 48,886 ha with the demand target of IDR 497,825.59 million.

Keywords: aquaculture development, ecological input-output, ecological footprint, Banten coastal zone

\section{PENDAHULUAN}

Mempertahankan pertumbuhan ekonomi merupakan salah satu agenda pembangunan ekonomi setiap wilayah. Berbagai cara dan kebijakan dilakukan agar tetap berada pada laju pertumbuhan ekonomi yang tinggi. Hal yang sama juga dilakukan oleh Provinsi Banten yang sedang giat-giatnya dalam melaksanakan pembangunan, sebagai provinsi yang relatif masih muda dan kaya akan sumberdaya alam, baik yang renewable maupun yang non-renewable. Provinsi ini berupaya untuk mempertahankan laju pertumbuhan ekonomi dengan cara memanfaatkan seluruh potensi sumberdaya alam yang tersedia.

Provinsi Banten memiliki garis pantai sepanjang $501 \mathrm{~km}$ dengan tiga muka pantai yaitu sebelah utara yang berhadapan dengan Laut Jawa, sebelah barat dengan Selat Sunda dan sebelah selatan dengan Samudera Hindia (BAPPEDA, 2002). Kemampuan Provinsi Banten dalam melakukan pengelolaan perikanan budidaya di wilayah pesisirnya telah memberikan total produksi sebesar $16.810,70$ ton dari budidaya tambak seluas $8.010,55$ ha dan budidaya laut seluas $11.882,00$ ha (BPS, 2006). Keseriusan pengelolaan perikanan budidaya di Provinsi Banten juga terlihat dengan dilaksanakannya Program Intensifikasi Budidaya Perikanan (INBUDKAN) yang kegiatannya meliputi kegiatan percontohan dan penguatan modal untuk memberdayakan masyarakat nelayan pembudidaya.

Selain itu, perikanan budidaya mampu menciptakan peluang usaha dan penyerapan tenaga kerja. Namun demikian, ternyata sisi lain yang terjadi berkurangnya areal hutan mangrove yang dikonversi menjadi tambak mengakibatkan menurunnya potensi sumberdaya alam hayati. Kerusakan dan konversi hutan mangrove ini terjadi di pantai utara, selatan dan barat Provinsi Banten, yang meliputi wilayah pesisir Kabupaten Serang, Kabupaten Tangerang dan Kecamatan Panimbang Kabupaten Pandeglang. Selama periode 2004 tercatat luas hutan mangrove di Provinsi Banten 2.374,11 ha kemudian pada tahun 2005 luas tersebut menurun menjadi $2.214,45$ ha (DKP, 2006). Dengan kata lain, terjadi penurunan luasan 6,73\% per tahun, angka ini lebih besar dari rata-rata penurunan luasan mangrove secara nasional $1,1 \%$ per tahun.

Implikasi dari hal ini dikarenakan kawasan pesisir merupakan kawasan yang rentan (vulnerable) terhadap perubahan lingkungan, yang akan menerima dampak negatif berupa pencemaran, sedimentasi, dan perubahan hidrologi serta penurunan keanekaragaman hayati (biodiversity loss) akibat aktivitas manusia dan pembangunan di daratan. Hal ini jika dibiarkan akan berakhir pada konflik penggunaan ruang karena sifat wilayah pesisir yang merupakan common property resource dengan pola pemanfaatan menjadi open access (siapa saja, kapan saja, dan berapa saja bebas menggunakan pesisir) yang akibatnya akan terjadi tragedy of the commons.

Oleh karena itu, untuk mempertahankan pertumbuhan ekonomi, baik melalui pemanfaatan sumberdaya alam, intensifikasi penggunaan lahan maupun industrialisasi memungkinkan timbulnya dampak terhadap lingkungan, atau sering dikatakan adanya trade-off antara sisi ekonomi dan ekologi. Namun demikian, dampak negatif dari kegiatan pembangunan ekonomi tidak berarti harus menghentikan atau mengurangi kegiatan pembangunan ekonomi, karena penghentian kegiatan pembangunan berarti akan menurunkan laju pertumbuhan ekonomi yang pada gilirannya akan menurunkan pendapatan masyarakat dan pada sisi lain akan 
meningkatkan pengangguran atau kemiskinan.

Hal tersebut mendorong perlunya suatu perencanaan pembangunan perikanan budidaya yang berkelanjutan terkait dengan daya dukung kawasan/wilayah pesisir itu sendiri. Dengan menekankan pada perhatian pemanfaatan lahan pesisir yang optimal dan diharapkan dengan adanya perencanaan perikanan budidaya bisa mengestimasi kemungkinan konsekuensi yang timbul. Selain itu, belum adanya studi tentang daya dukung lingkungan dilihat dari segi pemanfaatan lahan pesisir yang optimal untuk keberlanjutan, analisis daya dukung kawasan menjadi tantangan tersendiri dalam pengembangan ilmu yang ada. Tujuan penelitian ini adalah: 1). Menelaah kekuatan struktur dan interaksi antar sektor dari perikanan budidaya di Provinsi Banten; 2). Mengestimasi dampak terhadap ekonomi dan ekologi dari pembangunan perikanan budidaya di wilayah pesisir; dan 3). Mengestimasi daya dukung lingkungan pesisir yang dapat dimanfaatkan bagi kegiatan perikanan budidaya berkelanjutan.

\section{METODOLOGI}

Analisis ekonomi-ekologi digunakan dalam penelitian ini untuk mengkaji perencanaan pembangunan perikanan budidaya berkelanjutan (meliputi budidaya laut dan budidaya tambak) di wilayah pesisir Provinsi Banten, menggunakan pendekatan ecological footprint dan pengembangan analisis ecological inputoutput dengan aspek ekonomi-ekologi. Pada aspek ekonomi mencakup dampak dari kegiatan perikanan budidaya terhadap pendapatan dan ketersediaan lapangan kerja. Aspek ekologi meliputi input sumberdaya alam untuk kegiatan perikanan budidaya dalam hal ini berupa input lahan dan mangrove serta dampak yang terjadi terhadap lingkungan akibat kegiatan tersebut yang berupa limbah bahan organik.

\section{Jenis dan Sumber Data}

Jenis data yang digunakan dalam kajian ini adalah data sekunder yang diperoleh melalui penelusuran pustaka dan laporan dari berbagai instansi, yang meliputi: data fisik, sosial dan ekonomi, antara lain: Neraca Kualitas Lingkungan Hidup Daerah, Rencana Tata Ruang Wilayah Provinsi Banten dan Tabel Input-Output Provinsi Banten. Wawancara juga dilakukan kepada stakeholders dalam hal ini BAPPEDA untuk konfirmasi penggunaan lahan. Guna keperluan analisa disusun tabel Input-Output perikanan Banten yang diawali dengan perhitungan variabel penyusunnya. Tahapan ini merupakan tahapan yang paling lama dilakukan dan membutuhkan energi yang lebih karena ada tahap rekonsiliasi yang dilakukan berulang-ulang hingga tabel InputOutput perikanan yang disusun balance.

\section{Metode Analisis Data}

Ecological input-output digunakan untuk menelaah kekuatan struktur dan interaksi antar sektor dari perikanan budidaya dan mengestimasi dampak terhadap ekonomi dan ekologi dari pembangunan perikanan budidaya di wilayah pesisir yang meliputi multiplier ekonomi dan ekologi. Ecological input-output merupakan pengembangan dari model input-output (I-O) konvensional yang telah digunakan sebagai alat analisis perencanaan pembangunan selama ini (KMNLH dan BPS, 2000). Model ecological inputoutput dilakukan dengan cara memasukkan beberapa jenis komoditas ekologi, seperti air dan tanah ke dalam deretan sektor produksi dan menambahkan pada kolom-kolom terakhir beberapa output yang berupa limbah atau permasalahan lingkungan/ekologi seperti pencemaran dan sebagainya yang merupakan produk kegiatan ekonomi.

Prinsip analisis yang digunakan sama dengan prinsip pada analisis dasar, dimana dengan mengasumsikan koefisien konstan, maka dampak perubahan permintaan akhir pada produksi berbagai sektor (termasuk produksi limbah) akan bisa diprediksi. Karena model ini mencakup komoditi ekologi seperti air dan tanah yang dimasukkan sebagai input, maka dapat diprediksi dampak perubahan permintaan akhir pada besarnya kebutuhan input setiap sektor, sehingga dampaknya pada degradasi 
lingkungan dapat diperkirakan (KMNLH dan BPS, 2000).

Di samping itu, pendekatan ecological footprint digunakan untuk mengestimasi daya dukung lingkungan untuk kegiatan perikanan budidaya berkelanjutan. Pengaruh fisik pada perhitungan metodologi difokuskan pada ketersediaan lahan yang diperkenalkan oleh Wackernagel dan Rees (1996) dan secara umum direferensikan untuk ecological footprint (Hubacek dan Giljum, 2002). Oleh Wackernagel dan Rees (1996), ecological footprint didefinisikan sebagai total area lahan dan perairan yang dibutuhkan untuk mendukung suatu populasi dengan spesifik lifestyle dan pemberian teknologi terhadap kebutuhan sumberdaya alam dan mengabsorbsi semua buangan dan emisi dalam kurun waktu tertentu.

Lebih lanjut Adrianto (2006), menambahkan ecological footprint merupakan suatu konsep daya dukung lingkungan dengan memperhatikan tingkat konsumsi masyarakat, sehingga perbandingan ketersediaan lahan untuk populasi di suatu wilayah dengan ketersediaan ecological capacity, defisit atau surplus keberlanjutan dapat dikuantitatifkan.

Analisis carrying capacity di sini menggunakan pendekatan ecological footprint, dimana menurut Hubacek dan Giljum (2002) perhitungan ecological footprint adalah bagian dari kategori lahan built-up dan kesesuaian lahan langsung untuk infrastruktur, bukan pada dasar penggunaan lahan aktual atau data tutupan lahan, tetapi diawali dengan konsumsi sumberdaya oleh suatu populasi yang spesifik dalam unit massa.

Penggunaan ecological footprint dapat dilihat sebagai hal yang bermanfaat dengan suatu jalan yang berbeda untuk membuat kebijakan (Moffat et al., 2000). Yang fundamental dari metode ecological footprint adalah ide untuk menunjukkan areal lahan dalam beberapa tipe areal yang digunakan per kapita dari perhitungan terhadap populasi suatu wilayah. Model Haberl's digunakan sebagai model dasar perhitungan ecological footprint (Haberl et al., 2001), yaitu sebagai berikut :
$E F_{i}=\frac{D E_{i}}{Y_{\text {lok }} i}+\frac{I M_{i}}{Y_{\text {reg }} i}-\frac{E X_{i}}{Y_{l o k} i}$

dimana $E F_{\text {lok }}=\sum E F_{i}$

Keterangan :

$\mathrm{EF}_{\mathrm{i}}=$ Ecological Footprint produk ke-i $(\mathrm{Ha} /$ kapita)

$\mathrm{EF}_{\text {lok }}=$ Total Ecological Footprint (lokal) $(\mathrm{Ha} /$ kapita)

DE $=$ Domestic Extraction produk ke-i (Ton/ kapita)

$\mathrm{IM}_{\mathrm{i}}=$ Impor produk ke-i (Ton/ha)

$\mathrm{EX}_{\mathrm{i}}=$ Ekspor produk ke-i (Ton/ha)

$\mathrm{Y}_{\mathrm{lok} \mathrm{I}}=$ Yield (produktivitas) lokal produk ke-i (Ton/ha)

$\mathrm{Y}_{\text {reg I }}=$ Yield (produktivitas) regional produk ke-i (Ton/ha)

Sementara itu biocapacity (BC) dapat dihitung dengan menggunakan rumus:

$B C_{k}=A_{k} Y F$ dimana $B C_{l o k}=\sum A_{k} Y F$

Keterangan :

$\mathrm{A}_{\mathrm{k}}=$ Luas land cover kategori ke-k $(\mathrm{Ha})$

$\mathrm{YF}=$ Yield factor land cover kategori ke-k

Untuk yield factor land cover yang digunakan dalam perhitungan biocapacity pada pendekatan ecological footprint di sini, didasarkan pada tipe land use dan faktor pembobotan dari riset yang diperkenalkan oleh Lenzen dan Murray (2001) dan dapat dilihat pada Tabel 1.

\section{HASIL DAN PEMBAHASAN}

\section{Struktur Permintaan dan Penawaran}

Berdasarkan kajian terhadap struktur permintaan dan penawaran pada sektor perikanan budidaya (Tabel 2), dapat dijelaskan bahwa sektor perikanan budidaya penyebarannya hampir merata. Jumlah permintaan seluruhnya mencapai 218.391 juta rupiah. Dari jumlah tersebut 
Tabel 1. Faktor Pembobotan Lahan Menurut Tipe Penggunaan Lahan. Table 1. Weighting Factor by Land Use Type.

Tipe penggunaan lahan / Land use Type

Faktor Pembobotan/ Weighting Factor

- Lahan yang dibangun/ Built 1.00

- Lahan padang rumput atau tanaman yang terdegradasi akibat lahan tambang/ Degraded pasture or crop land Mined land

- Lahan padang rumput atau tanaman yang dibersihkan untuk perke bunan non-alami/ Cleared pasture and crop land Non-native planta tions

- Menipisnya taman padang rumput dan perkebunan taman nasional/ Thinned pasture Parks and gardens Native plantations

- Sebagian padang rumput terganggu (kebanyakan kering)/Partially disturbed pasture (mostly arid)

Sumber: Lenzen dan Murray (2001)/Source: Lenzen and Murray (2001)

Tabel 2. Struktur Permintaan dan Penawaran Perikanan Budidaya di Provinsi Banten (Juta Rp).

Table 2. Structure of Demand and Supply of Aquaculture in Banten Province (Million IDR).

\begin{tabular}{|c|c|c|c|c|c|c|}
\hline \multirow{2}{*}{ Sektor/Sector } & \multirow{2}{*}{$\begin{array}{c}\text { Permintaan } \\
\text { Antara / } \\
\text { Between } \\
\text { Demand }\end{array}$} & \multicolumn{2}{|c|}{$\begin{array}{l}\text { Permintaan Akhir/ } \\
\text { Final Demand }\end{array}$} & \multicolumn{2}{|c|}{$\begin{array}{c}\text { Penyediaan Input/ } \\
\text { Input Primer }\end{array}$} & \multirow{2}{*}{$\begin{array}{l}\text { Jumlah } \\
\text { Permintaan/ } \\
\text { Penawaran } \\
\text { / Sum of } \\
\text { Demand/ } \\
\text { Supply }\end{array}$} \\
\hline & & $\begin{array}{l}\text { Domestik/ } \\
\text { Domestic }\end{array}$ & $\begin{array}{l}\text { Ekspor/ } \\
\text { Ekspor }\end{array}$ & $\begin{array}{l}\text { Import/ } \\
\text { Import }\end{array}$ & $\begin{array}{l}\text { Domestik/ } \\
\text { Domestic }\end{array}$ & \\
\hline $\begin{array}{l}\text { Perikanan } \\
\text { budidaya/ } \\
\text { Aquaculture }\end{array}$ & 30,040 & 177,140 & 11,211 & 16,182 & 107,576 & 218,391 \\
\hline $\begin{array}{l}\text { Total Sektor/ } \\
\text { Total Sector }\end{array}$ & $52,426,415$ & $27,867,314$ & $28,800,957$ & $13,483,939$ & $43,184,332$ & $109,094,686$ \\
\hline
\end{tabular}

Sumber: Hasil Pengolahan Data Tabel Input-Output Tahun 2000/

Source:Processed Results of the Input-Output Table at of 2000

sebesar 30.040 juta rupiah atau sekitar $13,76 \%$ digunakan untuk memenuhi permintaan antara sektor produksi lainnya, memenuhi permintaan akhir domestik sebesar 177.140 juta rupiah $(81,11 \%)$ dan selebihnya untuk ekspor, yakni sebesar 11.211 juta rupiah $(5,13 \%)$ dari seluruh permintaan.

Namun demikian, jika dilihat dari sisi penawaran menunjukkan bahwa Provinsi Banten hanya mampu berperan menyediakan produksi perikanan budidaya sebesar 107.576 juta rupiah $(49,26 \%)$ dari seluruh penawaran/ penyediaan produk, kekurangannya yakni sebesar 16.182 juta rupiah $(7,41 \%)$ harus dipasok dari luar Provinsi Banten. Dengan adanya kekurangan pasokan sebesar 7,41\% menunjukkan bahwa di Provinsi Banten telah terjadi kekurangan pasokan (minus) dalam penyediaan produksi perikanan budidaya atau penawaran sektor perikanan budidaya lebih kecil dari permintaannya, dengan demikian secara keseluruhan sektor perikanan budidaya mengalami defisit sebesar 4.971 juta rupiah $(2,28 \%)$.

\section{Struktur Permintaan Akhir}

Hasil analisis terhadap sektor perikanan budidaya yang disajikan pada Tabel 3 menunjukkan bahwa permintaan akhir sektor ini paling banyak digunakan untuk konsumsi rumah tangga yaitu sebesar $94,75 \%$, dan 
ekspor sebesar 5,95\%, sedangkan untuk konsumsi pemerintah, pembentukan modal tetap sama sekali tidak ada, bahkan terjadi minus $0,7 \%$ untuk perubahan stok sehingga diperlukan impor untuk mengatasi hal tersebut. Interpretasi dari hal ini ternyata produksi perikanan budidaya lebih banyak digunakan untuk konsumsi rumah tangga baik langsung maupun tidak langsung dibandingkan untuk kegiatan produksi sektor lainnya.

Nilai investasi yang terbentuk di sektor perikanan budidaya tidak ada, terbukti dengan pembentukan modal tetap sama sekali tidak ada. Hal ini perlu mendapat perhatian khusus dari pemerintah dan semua stakeholder, jika diinginkan sektor ini menjadi sektor andalan dimana salah satu alternatifnya adalah dengan meningkatkan investasi melalui pemberian insentif.

\section{Struktur Input Primer}

Struktur input primer merupakan semua jenis balas jasa yang dibayarkan kepada sektor ekonomi sebagai kompensasi atas keterlibatannya dalam kegiatan perikanan budidaya. Pada Tabel 4 kegiatan usaha perikanan budidaya relatif lebih memberikan proporsi yang menguntungkan dibanding kegiatan ekonomi lainnya, ditunjukkan dengan surplus usaha sebesar 79.357 juta rupiah $(73,77 \%)$ dari total nilai output. Angka ini lebih besar dari rata-rata surplus usaha semua sektor ekonomi wilayah (52,39\%). Ini menunjukkan bahwa dalam pembentukan output di sektor perikanan budidaya, komponen surplus usaha memegang peranan penting. Jika dibandingkan dengan tingkat suku bunga perbankan yang berkisar antara $6 \%$ hingga $12 \%$ per tahun, maka surplus usaha ini jauh lebih tinggi. Hal ini merupakan daya tarik tersendiri bagi para investor untuk menanamkan modalnya di sektor ini.

Tabel 3. Komposisi Permintaan Akhir Perikanan Budidaya Menurut Komponennya.

Table 3. Composition of Final Demand Aquaculture According to Components.

\begin{tabular}{lcr}
\hline \multicolumn{1}{c}{ Komponen/Componen } & \multicolumn{2}{c}{$\begin{array}{c}\text { Sektor Perikanan Budidaya/ } \\
\text { Aquaculture Sector }\end{array}$} \\
\cline { 2 - 3 } & $\begin{array}{c}\text { Nilai (Juta Rp)/ } \\
\text { Value (Million IDR) }\end{array}$ & \% \\
\hline Konsumsi rumah tangga/ Household consumption & 178,465 & 94.75 \\
Konsumsi pemerintah/ Government consumption & 0 & 0.00 \\
Pembentukan modal tetap/ Fixed capital formation & 0 & 0.00 \\
Perubahan stok/ Stock changes & $(1,325)$ & $(0.70)$ \\
Ekspor/ Eksport & 11,211 & 5.95 \\
\hline Jumlah permintaan akhir/Final demand total & $\mathbf{1 8 8 , 3 5 1}$ & $\mathbf{1 0 0 . 0 0}$ \\
\hline
\end{tabular}

Sumber: Hasil Pengolahan Data Tabel Input-Output Tahun 2000/

Source:Processed Results of the Input-Output Table at of 2000

Tabel 4. Beberapa Komponen Input Primer Perikanan Budidaya dan Sektor Basis.

Table 4. Some Components of the Primary Input Aquaculture and Sector Basis.

\begin{tabular}{lrrrrrr}
\hline $\begin{array}{c}\text { Komponen/ Com- } \\
\text { ponents }\end{array}$ & $\begin{array}{c}\text { Perikanan Budi- } \\
\text { daya/ Aquacul- } \\
\text { ture }\end{array}$ & $\begin{array}{c}\text { Pertanian/ } \\
\text { Agriculture }\end{array}$ & $\begin{array}{c}\text { Industri/ } \\
\text { Industry }\end{array}$ & $\begin{array}{c}\text { Perdagangan/ } \\
\text { Trade }\end{array}$ & $\begin{array}{c}\text { Lainnya/ } \\
\text { Others }\end{array}$ & $\begin{array}{c}\text { Jumlah/ } \\
\text { Quantity }\end{array}$ \\
\hline Upah dan gaji/ & 18,603 & $2,205,411$ & $6,653,583$ & $1,686,513$ & $3,523,090$ & $14,087,200$ \\
Wages and salaries & 17.29 & 54.33 & 29.07 & 22.21 & 41.28 & 32.62 \\
Surplus usaha/ & 79,357 & $1,577,182$ & $12,777,254$ & $5,000,944$ & $3,189,948$ & $22,624,685$ \\
Surplus effort & 73.77 & 38.86 & 55.81 & 65.86 & 37.38 & 52.39 \\
\hline & 107,576 & $4,059,114$ & $22,889,689$ & $7 ., 593,761$ & $8,534,192$ & $43,184,332$ \\
Jumlah/Total & 100.00 & 100.00 & 100.00 & 100.00 & 100.00 & 100.00 \\
\hline
\end{tabular}

Sumber: Hasil Pengolahan Data Tabel Input-Output Tahun 2000/

Source:Processed Results of the Input-Output Table at of 2000 
Namun demikian, tingkat upah dan gaji yang diterima masyarakat nelayan relatif kecil dibanding dengan kegiatan ekonomi lainnya yaitu sebesar 18.603 juta rupiah $(17,29 \%)$. Angka tersebut lebih kecil dari rata-rata semua sektor ekonomi dalam membayar pekerja yaitu sebesar $32,62 \%$. Padahal upah dan gaji merupakan satu-satunya komponen nilai tambah yang bisa langsung diterima oleh pekerja (buruh nelayan). Upah dan gaji yang relatif lebih kecil secara langsung dan tidak langsung akan mempengaruhi daya beli masyarakat (buruh nelayan).

\section{Keterkaitan Sektor Perikanan Budidaya}

Sektor perikanan budidaya mempunyai nilai Backward Linkages (BL) yang lebih besar yaitu sebesar 1,8378 dibandingkan dengan nilai Forward Linkages (FL) yang hanya sebesar 1,0198. Hal ini berarti bahwa sektor perikanan budidaya mempunyai daya serap input yang tinggi dibandingkan dengan daya dorong outputnya. Daya serap tersebut sebagian besar dilakukan terhadap sektor industri yaitu sebesar 67.061 juta rupiah $(30,71 \%)$ dan sektor perdagangan, hotel dan restoran sebesar 13.530 juta rupiah $(6,20 \%)$.

Dengan kata lain dapat dikatakan bahwa perikanan budidaya mempunyai daya penyebaran yang lebih tinggi dibandingkan dengan derajat kepekaannya. Hal ini berarti bahwa sektor perikanan budidaya lebih kuat dipengaruhi oleh sektor-sektor penyedia input daripada dengan sektor-sektor pengguna output sektor yang bersangkutan. Gambar 1 adalah ilustrasi pengelompokkan sektor kegiatan berdasarkan daya penyebaran dan derajat kepekaan. Perikanan Budidaya dinotasikan dengan angka 2.

Gambar 1 terlihat bahwa perikanan budidaya mempunyai indeks daya penyebaran tinggi dengan indeks derajat kepekaan rendah sehingga dikategorikan sebagai sektor Potensial, karena sektor tersebut mempunyai daya dorong yang lebih kecil dari rata-rata semua sektor, tetapi mempunyai daya tarik yang lebih besar dari rata-rata semua sektor. Di Provinsi Banten yang termasuk kelompok ini adalah perikanan budidaya, sektor konstruksi (6) dan sektor transportasi dan komunikasi (8). Namun demikian, sektor industri (4) masih menjadi sektor andalan di Provinsi Banten.

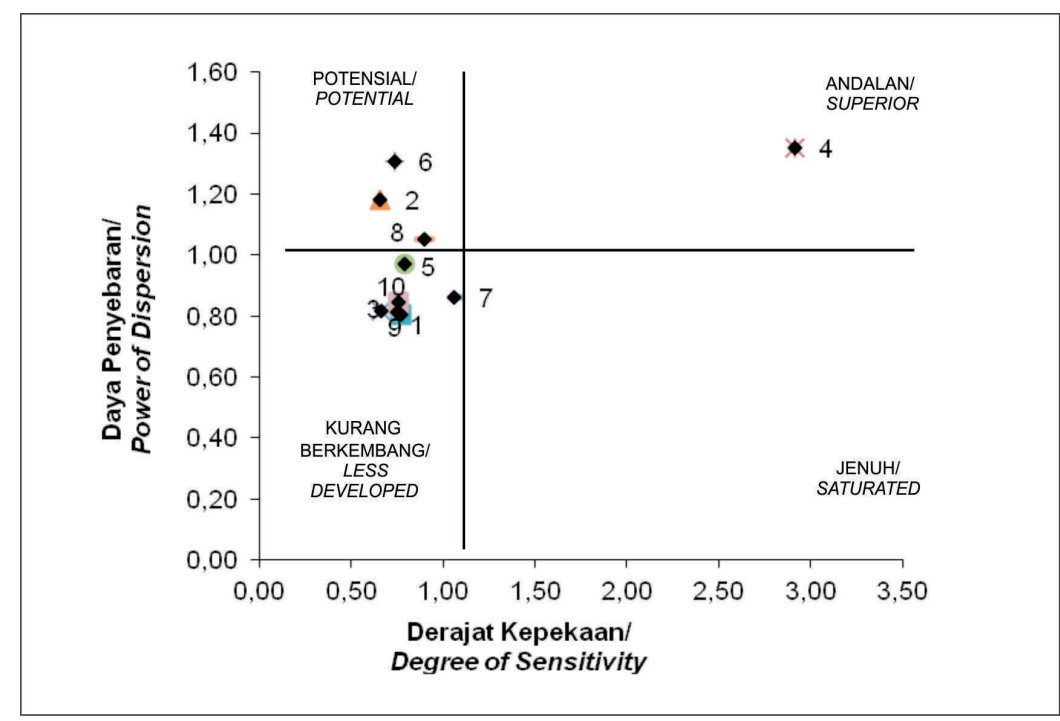

\footnotetext{
Gambar 1. Pengelompokkan Sektor Kegiatan Berdasarkan Daya Penyebaran dan Derajat Kepekaan.
}

Figure 1. Grouping of Activities Sector Based on the Power of Dispersion and the Degree of Sensitivity. 


\section{Dampak Ekonomi Pembangunan Perikanan Budidaya}

Kegiatan usaha perikanan budidaya pada umumnya secara langsung dan tidak langsung berdampak positif terhadap ekonomi masyarakat nelayan. Sejauh mana dampak ekonomi yang tercipta dapat ditunjukkan pada Tabel 5 yaitu nilai income multiplier dan employment multiplier. Analisis income multiplier menunjukkan bahwa sektor perikanan budidaya mempunyai nilai income multiplier sebesar 2,20 yang berada di atas rata-rata pembentukan pendapatan masyarakat secara sektoral sebesar 1,58 . Nilai tersebut menunjukkan bahwa untuk setiap peningkatan satu juta rupiah permintaan akhir di sektor perikanan budidaya akan menyebabkan peningkatan pendapatan sebesar 2,20 kali. Informasi ini memberi petunjuk bahwa dari sisi pengganda pendapatan sektor perikanan budidaya cukup andal dalam menciptakan pendapatan masyarakat nelayan.

Analisis employment multiplier menunjukkan bahwa sektor perikanan budidaya memiliki nilai sebesar 1,17 berada di bawah rata-rata total pembentukan lapangan kerja secara sektoral yang sebesar 1,57. Nilai tersebut menunjukkan bahwa untuk setiap peningkatan satu juta rupiah permintaan akhir akan menyebabkan peningkatan penyerapan tenaga kerja sebanyak 1,17 orang. Informasi ini memberi petunjuk bahwa dari sisi pengganda tenaga kerja sektor perikanan budidaya belum cukup andal dalam menciptakan kesempatan kerja pada masyarakat nelayan. Hal ini perlu mendapat perhatian khusus dikarenakan upah dan gaji yang diterima oleh tenaga kerja di sektor tersebut relatif lebih rendah dibandingkan dengan surplus usaha yang diterima oleh pengusaha.

\section{Dampak Ekologi Pembangunan Perikanan Budidaya}

Tinjauan ekologi dilakukan terhadap sumberdaya yang dimanfaatkan dalam pembangunan perikanan budidaya antara lain: lahan untuk produksi dan ekosistem mangrove sebagai input dari ekosistem serta polutan/ limbah bahan organik sebagai eksternalitas yang dihasilkan akibat kegiatan perikanan budidaya. Analisis ecological multiplier menunjukkan bahwa kebutuhan tertinggi area lahan terjadi pada sektor pertanian dengan nilai 0,1394, sedangkan perikanan budidaya menempati posisi kedua dengan nilai sebesar 0,0982 (Tabel 6) yang berada di atas rata-rata kebutuhan area secara sektoral sebesar 0,0403 . Hal ini mengindikasikan bahwa untuk menghasilkan satu juta rupiah output bagi sektor perikanan budidaya baik secara langsung maupun tidak langsung dibutuhkan area tanah seluas 0,0982 ha. Demikian juga untuk menghasilkan satu juta rupiah output sektor perikanan budidaya dibutuhkan area mangrove seluas 0,0103 ha.

Tabel 5. Income Multiplier dan Employment Multiplier Perikanan Budidaya Table 5. Income Multiplier and Employment Multiplier aquaculture

\begin{tabular}{lcc}
\hline \multicolumn{1}{c}{ Sektor/Sector } & Income Multiplier & Employment Multiplier \\
\hline Perikanan budidaya/ Aquaculture & 2.20 & 1.17 \\
\hline Rata-rata per sektor/The average per sector & 1.58 & 1.57 \\
\hline
\end{tabular}

Sumber: Hasil Pengolahan Data Tabel Input-Output Tahun 2000/

Source:Processed Results of the Input-Output Table at of 2000

Tabel 6. Kebutuhan Area dan Mangrove Serta Limbah Bahan Organik Perikanan Budidaya. Table 6. Area and Mangrove Needs and Waste Materials Organic Aquaculture.

\begin{tabular}{lcccccc}
\hline \multicolumn{1}{c}{ Sektor/Sector } & Area & Mangrove & BOD & COD & TSS & TDS \\
\hline Perikanan Budidaya/ Aquaculture & 0,0982 & 0,0103 & 0,0006 & 0,0011 & 0,0004 & 0,0010 \\
\hline $\begin{array}{l}\text { Rata-rata per sektor/ } \\
\begin{array}{l}\text { Average per sector } \\
\text { Surat }\end{array}\end{array}$ & $\mathbf{0 , 0 4 0 3}$ & $\mathbf{0 , 0 0 1 0}$ & $\mathbf{0 , 0 0 1 0}$ & $\mathbf{0 , 0 0 1 7}$ & $\mathbf{0 , 0 0 0 7}$ & $\mathbf{0 , 0 0 1 6}$
\end{tabular}

Sumber: Hasil Pengolahan Ecological Input-Output Tahun 2000/

Source:Processed Results of the Ecological Input-Output at of 2000 
Sedangkan analisis ecological multiplier dari sisi polutan/limbah bahan organik yang dihasilkan dari kegiatan perikanan budidaya menunjukkan bahwa perikanan budidaya dalam menghasilkan eksternalitas masih berada di bawah rata-rata ekternalitas secara sektoral. Implikasi dari hal ini dapat diketahui bahwa sektor perikanan budidaya meskipun merupakan sektor yang potensial ternyata dalam menghasilkan pencemaran bahan organik masih relatif lebih rendah dibandingkan sektor potensial lainnya.

\section{Ecological Footprint}

Ecological footprint (EF) merupakan suatu konsep daya dukung lingkungan dengan memperhatikan tingkat konsumsi masyarakat (Adrianto 2006). Analisis footprint di suatu wilayah didasarkan pada kegiatan konsumsi, ekspor dan impor yang dilakukan oleh wilayah tersebut.
Berdasarkan hasil analisis footprint yang disajikan pada Gambar 2 dan Gambar 3, ratarata area yang dibutuhkan untuk budidaya laut di wilayah pesisir Provinsi Banten adalah 1.135.157 ha atau 1,2 kali dari luas total wilayah Provinsi Banten ( 943.833 ha). Jika dibandingkan dengan area produktif untuk budidaya laut seluas 48.886 ha, maka area yang dibutuhkan 23 kali dari luas areal produktif.

Rata-rata area yang dibutuhkan untuk budidaya tambak di wilayah pesisir Provinsi Banten adalah 130.183 ha atau 0,13 kali dari luas total wilayah Provinsi Banten (943.833 ha). Jika dibandingkan dengan area produktif untuk budidaya tambak seluas 11.707 ha, maka area yang dibutuhkan 11,12 kali dari luas areal produktif.

Secara singkat dapat dikatakan bahwa Provinsi Banten saat ini terjadi "ecological defisit" untuk budidaya laut dan budidaya tambak. Namun demikian, perlu diingat bahwa

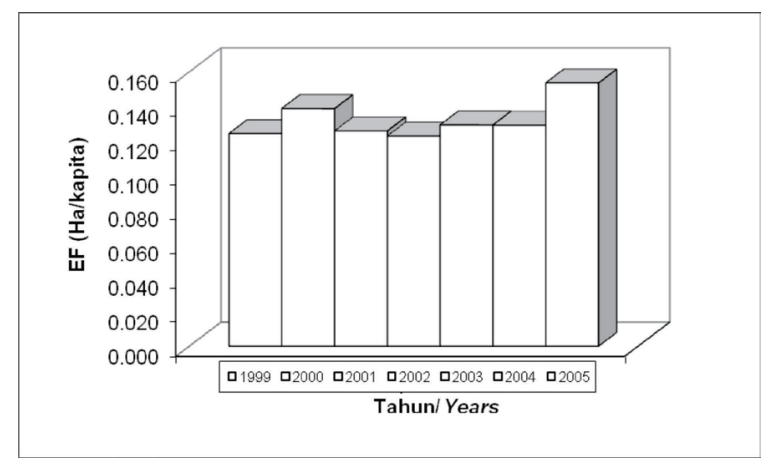

Gambar 2. Ecological Footprint Budidaya Laut Provinsi Banten Figure 2. Ecological Footprint of Mariculture in Banten Province

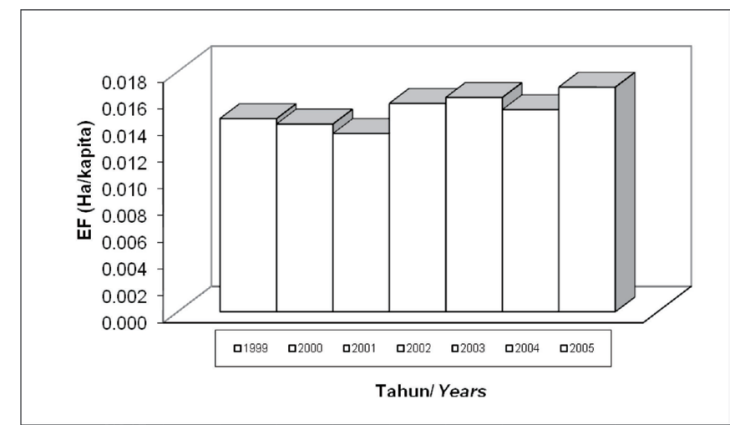

Gambar 3. Ecological Footprint Budidaya Tambak Provinsi Banten

Figure 3. Ecological Footprint of the Aquaculture Pond in Banten Province 
daerah yang ecological defisit belum tentu "tidak makmur" dalam konotasi ekonomi karena tidak semua kebutuhan manusia dapat dipenuhi oleh sumberdaya alam dan lingkungan setempat. Daerah yang ecological defisit juga dapat makmur jika hasil dari sumberdaya alam yang tersedia dapat dipasarkan secara sehat untuk ditukarkan dengan kebutuhan hidup lain yang tidak dapat dipenuhi oleh sumberdaya dan lingkungan setempat. Jika dibandingkan dengan beberapa negara dan dunia, ecological footprint dari budidaya laut dan budidaya tambak Provinsi Banten memiliki nilai yang lebih kecil dibandingkan negara lain, sebagai contoh: Singapura 6,9 ha/kapita (Vitner et al., 2006) dan Dunia 0,3 ha/kapita (WWF, 2002).

\section{Linkage Ecological Footprint (EF) dan Ecological Input-Output (EIO)}

Hasil analisis dari EIO diperoleh bahwa untuk memenuhi target permintaan sebesar satu juta rupiah output perikanan budidaya diperlukan areal lahan seluas 0,0982 ha dan atau mangrove seluas 0,0103 ha. Hal ini memberikan hubungan bahwa untuk membuka suatu usaha budidaya baik laut maupun tambak sangat tergantung pada target permintaan yang ingin dipenuhi. Semakin besar target permintaan yang ingin dicapai, maka semakin besar pula areal dan mangrove yang dibutuhkan. Hubungan EF dengan EIO dalam bentuk area untuk perikanan budidaya disajikan pada Gambar 4.

Areal yang optimum untuk budidaya laut yaitu pada level 48.886 ha atau sejalan dengan biocapacity, dengan target permintaan yang dapat dipenuhi sebesar 497.825,59 juta rupiah. Budidaya tambak, areal yang optimum hanya pada level 11.707 ha dengan target permintaan yang dapat dipenuhi sebesar $119.217,04$ juta rupiah. Dari hubungan EF dan EIO untuk perikanan budidaya khususnya dalam bentuk area, diperoleh suatu persamaan yaitu : $A=0,0982$ y, Dimana: $A=$ Areal tanah (ha), dan $y=$ Target permintaan yang ingin dipenuhi (juta rupiah).

Persamaan di atas bisa digunakan dalam merencanakan pembangunan perikanan budidaya di Provinsi Banten khususnya untuk mengetahui berapa besar areal yang dibutuhkan untuk usaha budidaya (laut atau tambak) berdasarkan pada target permintaan yang ingin dipenuhi. Namun demikian, perlu diingat batasan biocapacity sebagai sebuah ukuran ketersediaan lahan produktif secara ekologis, sehingga dalam pemanfaatannya tidak boleh melebihi agar pembangunan yang berkelanjutan terpenuhi.

Selain itu, hubungan EF dan EIO untuk perikanan budidaya khususnya dalam keperluan area mangrove diperoleh suatu persamaan yaitu: $M=0,0103 \mathrm{y}$, Dimana: $M=$ Area Mangrove (ha), dan $\mathrm{y}=$ Target permintaan

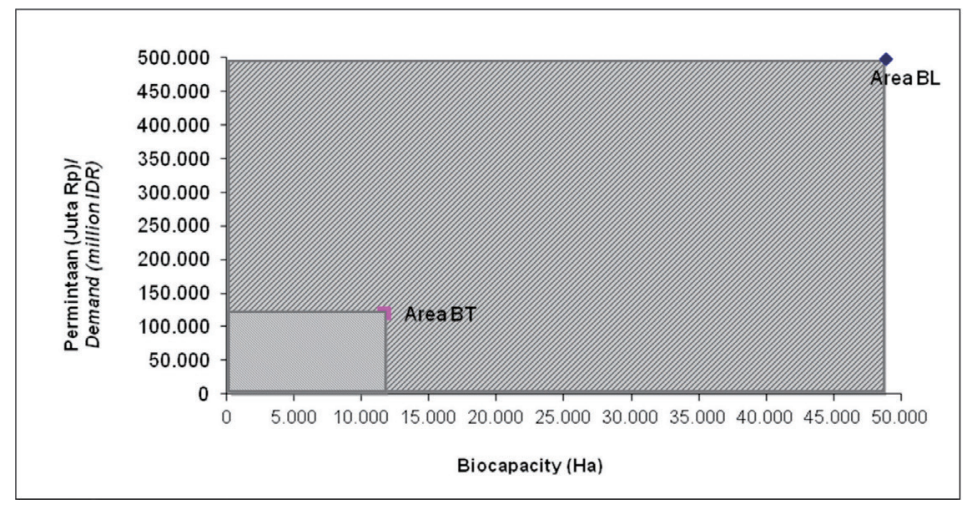

Gambar 4. Hubungan Ecological Footprint dan Ecological Input-Output dalam Bentuk Area untuk Perikanan Budidaya.

Figure 4. Ecological Footprint and Ecological Input-Output Relationships in the form of Area for Aquaculture. 
yang ingin dipenuhi (juta rupiah). Persamaan ini bisa digunakan dalam merencanakan pembangunan perikanan budidaya di Provinsi Banten khususnya untuk mengetahui berapa besar mangrove yang dibutuhkan untuk usaha budidaya (laut atau tambak) berdasarkan pada target permintaan yang ingin dipenuhi. Namun demikian, perlu diingat batasan biocapacity untuk mangrove itu sendiri. Ternyata di Provinsi Banten luas mangrove hanya sebesar $2.214,45$ ha, hal ini bisa menjadi perhatian dan pertimbangan yang optimum oleh pengambil kebijakan dalam merencanakan pembangunan perikanan budidaya agar lebih berwawasan lingkungan untuk pembangunan berkelanjutan.

\section{KESIMPULAN DAN IMPLIKASI KEBIJAKAN}

\section{Kesimpulan}

Ditinjau dari kekuatan struktur perikanan budidaya Provinsi Banten cenderung digunakan untuk keperluan konsumsi baik langsung maupun tidak langsung dibandingkan untuk kegiatan produksi. Namun demikian, perikanan budidaya termasuk dalam kategori sektor potensial untuk dikembangkan. Implikasi dari hal ini ditunjukkan bahwa perikanan budidaya mempunyai daya serap input yang tinggi dibandingkan dengan daya dorong outputnya, atau dengan kata lain lebih kuat dipengaruhi oleh sektor-sektor penyedia input dibanding dengan sektor-sektor pengguna outputnya.

Berdasarkan estimasi dampak ekonomi yang muncul dari pembangunan perikanan budidaya ternyata perikanan budidaya cukup andal dalam meningkatkan pendapatan masyarakat nelayan, tetapi belum cukup andal dalam menciptakan kesempatan kerja. Hal ini sejalan dengan surplus usaha yang diterima oleh pengusaha yang relative lebih besar dibandingkan dengan upah dan gaji yang diterima oleh tenaga kerja di sektor tersebut, sehingga berimplikasi pada rendahnya keinginan bekerja di sektor ini dan lebih tertarik di sektor lain. Selain itu, estimasi dampak ekologi dari pembangunan perikanan budidaya ternyata perikanan budidaya membutuhkan input lingkungan di atas rata-rata kebutuhan area dan mangrove secara sektoral. Namun demikian, eksternalitas yang ditimbulkan dari perikanan budidaya masih berada di bawah rata-rata ekternalitas secara sektoral.

Analisis daya dukung lingkungan menunjukkan bahwa perikanan budidaya Provinsi Banten mengalami ecological defisit. Daya dukung lingkungan pesisir yang dapat dimanfaatkan untuk budidaya laut yaitu pada level 48.886 ha dengan target permintaan optimum 497.825,59 juta rupiah, sedangkan budidaya tambak pada level 11.707 ha dengan target permintaan optimum 119.217,04 juta rupiah.

\section{Implikasi Kebijakan}

Dalam melakukan pembangunan perikanan budidaya perlu memperhatikan keberadaan sektor industri dan sektor perdagangan, hotel dan restoran, karena sektor tersebut memiliki daya tarik dan daya dorong yang besar terhadap perikanan budidaya. Sehingga pembangunan tidak bersifat sektoral melainkan lintas sektoral, dan keterkaitan dengan sektor tersebut akan semakin kuat.

Di samping itu, untuk mendukung hal tersebut kebijakan terhadap iklim investasi dan usaha khususnya di sektor perikanan budidaya juga menjadi perhatian utama jika ingin sektor ini menjadi sektor andalan. Dengan tingkat surplus usaha yang diatas rata-rata dari sektor lainnya, ini bisa menjadi modal tersendiri untuk menarik minat para investor. Namun perlu diperhatikan juga tingkat upah dan gaji yang diterima oleh masyarakat nelayan agar daya beli tetap terjaga dan terjadi keseimbangan dalam kegiatan produksinya.

Terkait dengan perencanaan pembangunan berkelanjutan, hendaknya lebih memperhatikan mariculture sebagai sebuah solusi implikasi kebijakan dari keberlanjutan perikanan budidaya. Hal ini dikarenakan dukungan biocapacity yang lebih besar sehingga mampu memberikan target permintaan yang optimum, dengan tetap menjaga kelangsungan ekosistem mangrove. 


\section{DAFTAR PUSTAKA}

Adrianto, L. 2006. Pengelolaan Pulau-Pulau Kecil Berkelanjutan: Tantangan Riset dan Akademik. Disampaikan pada Mukernas Himitekindo Bogor, 16 Januari 2006. PKSPLIPB. Bogor.

Anonim. 2000. Modul Pelatihan Model Ekonomi Makro untuk Analisis Lingkungan di Indonesia. Kerjasama antara Pemerintah Kerajaan Norwegia Kantor Menteri Negara Lingkungan Hidup dan Biro Pusat Statistik. Jakarta.

. 2002. Rencana Tata Ruang Wilayah Provinsi (RTRWP) Banten 2002-2017. Badan Perencanaan Pembangunan Daerah Provinsi Banten (BAPPEDA) Banten. . 2006. Banten Dalam Angka 2005. Badan Pusat Statistik Provinsi Banten. Banten. 2006. Pedoman Pengelolaan Ekosistem Mangrove. Direktorat Jenderal Kelautan, Pesisir \& Pulau-Pulau Kecil, Departemen Kelautan dan Perikanan. Jakarta.

Haberl, Heinz, E.K., and F. Krausmann. 2001. How to Calculate and Interpret Ecological Footprints For Long Periods of Time: The Case of Austria 1926-1995. Ecological Economics 38 : 25-45.
Hubacek, K., and S. Giljum. 2002. Applying Physical input-output analysis to estimate land appropriation (ecological footprints) of international trade activities. J. Ecological Economics 44:137-151.

Lenzen, M. and S.A. Murray. 2001. A Modified Ecological Footprint Method and Its Application to Australia. J Ecological Economics 37:229-255.

Moffat, I., Hanley, N. and M.D. Wilson. 2000. Measuring and Modeling Sustainable Development. Parthenon Publishing. Bristol, UK.

Vitner, Y., Susilo, S.B. dan Aminuddin. 2006. Model Daya Dukung "Ecological Footprint" Pulau-Pulau Kecil (Studi Kasus Pulau Wetar). Disampaikan pada Seminar 10 Tahun PKSPL IPB. Bogor, 15 Agustus 2006. PKSPL-IPB. Bogor.

Wackernagel, M. and Rees. 1996. Our Ecological Footprint: Reducing Human Impact on The Earth. New Society Publishers, Gabriola Island. British Columbia.

WWF. 2002. Assessing The Ecological Footprint. A Look at The WWF's Living Planet Report 2002. Environmental Assessment Institute. Denmark. 